\title{
PROBLEMS OF SCHEDULED TRIBES STUDENTS : A SOCIOLOGICAL STUDY
}

\section{[With Reference to the Students of Medical Colleges of Ahmedabad City]}

\section{Abstract :}

\section{Dr. Nitinkumar K. Jadav}

Many social groups are living in India. The social and economic development of various castes is not equal. We can see the inequalities in terms of their wealth, political powers and social status. Some of the casts have improved their social status by acquiring political and economic powers. Scheduled castes and scheduled tribes could not improve their social status at par with other castes. To know various problems of scheduled tribe students. Survey method is used in this research study. Two medical colleges of Ahmadabad city have been selected for this study, 100 students of Scheduled tribe are selected as respondents who are studying in M.B.B.S. The students of scheduled tribe who are easily available are selected as respondents. Information is collected through interview schedule is asking quantitative and qualitative questions.

Key words. Scheduled Tribes, Students, Problems, Medical Colleges.

\section{$\star \quad$ Introduction :}

In the world any social system is not steady according to changing time, occasionally changes come. Like that changes come in tribal communities. Tribals come into contract with other society, changes come in their social, economical, educational political and religious matter. Some tribals have taken more education and joined business which give them higher income. Some tribals migrated from rural to 


\section{Dr. Nitin Jadav / Page 33-38}

urban areas. In this manner, various changes are seen among tribals. At present students of tribal communities are studying various disciplines in the field of education. This study has been done with sociological perspective among the students of scheduled tribe communities in medical field.

\section{$\star \quad$ Objectives of the Study:}

To know various problems of scheduled tribe students and investigate various family problems, economical problems, debt problems, linguistic problems and mental stress faced during the study.

\section{* Methodology :}

Survey method is used in this research study. Two medical colleges of Ahmedabad city have been selected for this study, one is B.J. Medical College and another is N.H.L. Municipal Medical College. From both colleges 100 students of Scheduled tribe are selected as respondents who are studying in M.B.B.S. The students of scheduled tribe who are easily available are selected as respondents. Information is collected through interview schedule is asking quantitative and qualitative questions.

\section{* Importance of the Study :}

This study is useful to understand various problems and their solutions among students of scheduled tribe who are studying in medical colleges of Ahmedabad City. This study is also useful to know the situation of social, economical and educational matter among students of scheduled tribe. What is social situation of scheduled tribe students who are studying in medical field? It is also useful to understand ideas of the students in medical field, impact of economical condition on education among students of scheduled tribe. Various schemes are run by the government particularly for the students of scheduled tribe. This study is important and useful for formulating various programmes and schemes for the students of scheduled tribe. This study is also important to understand the situation of scheduled tribe students and their awareness about situation in medical field.

\section{* Limitation of the Study :}

This study is limited only for the students of scheduled tribe who are studying in medical colleges of Ahmedabad. Students of other categories are not included in this study. The field of this study is limited. So its conclusions cannot applied for the whole world entirely. All the 
aspects are not covered in this study. It is limited only for the students of scheduled tribe of medical college.

\section{* Conclusions:}

- $61 \%$ respondents or students of scheduled tribe have selected medical field by their parent's choice. While 30\% respondents have selected medical field by themselves. They have taken admission in medical field for help and services of the society.

- $\quad 81 \%$ respondents have not faced any problem for career selection in medical college. While remaining $19 \%$ faced problems in selection of career in medical field. They faced problems regarding lack of proper guidance and economic solvency.

- $\quad$ All the respondents have said that their family members and other relative have given assistance and co-operation for the study in medical field.

- Majority of the respondents (86\%) are satisfied with teaching method of their professors in medical college.

- $\quad 45 \%$ students of scheduled tribe faced lauguage problems during the study in medical college. That is to understand concepts related with medical field.

- $\quad 29 \%$ students faced financial problems due to study medical field. Whereas $8 \%$ students father have done debt. While majority i.e. $81 \%$ scheduled tribe students said that they have not experienced any financial problems for the study in medical field, due to jobs of their parents and good economic conditions.

- $\quad 88 \%$ students of scheduled tribe have enough time for practical and assignment during their study in medical college.

- $\quad 37 \%$ students of scheduled tribe have experienced of mental stress during their study in medical college. But, majority i.e. 92\% respondents said that they have not faced health problems during their study. Only $8 \%$ respondents faced health problems during their study in medical field.

- $\quad 31 \%$ students of scheduled tribe said that their parents or relatives have not experienced any financial problems during their study.

- $18 \%$ tribal students said that they faced problems of injustice for admission in medical colleges like if seats are not enrolled they converted into reserved seats, reservation seats are not enough. Due to this, scheduled tribe students faced injustice problem in matter of admission in medical field. $18 \%$ respondents have represent such things.

- $\quad 79 \%$ scheduled tribe students unable to remain present in homely social occasions because of their study in medical field. 
- In this study majority (72\%) of the tribal students are of the opinion that due to lower income of family scheduled tribe students could not study in medical field.

- In this study, majority (82\%) respondents are of the opinion that they could not study in medical field without financial aid. Scholarship was the only sources for financial assistance.

- $\quad 97 \%$ scheduled tribe students said that they do not get any assistant from their community or any other community organisations and whichever help they get is in form of scholarship from the government. 50\% respondents do not get scholarship in time which creates more conflict in financial assistance to them.

- In selection of life partner, 52\% tribal students are of the opinion that they will select life partner according to their parents as well as self choice or selection. While $24 \%$ students have given preference for self selection. Which means changes are seen in matter of selection of life partner.

- $\quad 88 \%$ students of scheduled tribe stayed in hostel. They stayed in hostel due to facility is not available in their native place or far from native place and lack of sound economic condition.

- $\quad 72 \%$ tribal students said that hostel environment is not obstructing in their study.

- $\quad 28 \%$ students of scheduled tribe who are studying in medical field are of the opinion that groupism is seen in colleges, there in 3\% students faced problem of groupism and $16 \%$ students are of the opinion that there is a support of political party or community party support behind groupism.

- $\quad 30 \%$ students victimized raging problem in college or hostel. While 5\% students of scheduled tribe faced victimization problem in medical field.

- In this majority (99\%) of respondents are of the opinion that in tribal society importance of doctor is seen more than BhagatBhuva.

- Majority of the respondents $(95 \%)$ said that they will give services in their native places after they become doctor. 


\section{$\star \quad$ References}

1. Joshi Vidhyut (1998) "Tribal Situation in India", Rawat Publications, Jaipur and New Delhi.

2. Shah B.V. (1964) "Social Change in College students of Gujarat", M.S. University of Baroda Press.

3. Shah Darlesh L. Wedding Danna Zeldow Peter B. Diehl Nancy. "The Physician and Society" - Chapter-6 Special Problems of Medical Students.Source :www.medicalstudentsproblems.

4. ShethMahendra Kumar (2006) "SC/ST Students Access to Education Challenges and Opportunities", Abhijeet Publication, Delhi

5. UpadhyayChandrakant (2009) "Adivasi :Parampara and Parivartan", NavbharatSahityaMandir, Ahmedabad.

6. Shah Vimal (1964)“AdivasionaPrashno", AdivasiShanshodhan and Talim Kendra Prakashan Mala, Gujarat Vidyapeeth, Ahmedabad.

7. Shah Vimal (1964) "Gujarat Na Adivasio)", Gujarat Vidyapeeth, Ahmedabad.

8. MasviMustaali E. (1991) "AdivasioniPaltatiArthikSthitinoAbhyas", Gujarat Vidyapeeth, Ahmedabad.

9. Patel Bhagwandas (1999) “AdivasoOlakh”, MahitiKhatu, Gujarat Rajya, Gandhinagar.

10. Desai Haribhai G. Desai Krishnakant G. (1985) "ShanshodhanPaddhatioAnePravidhio", University GranthNirman Board, Ahmedabad.

$\star \quad$ Journals / Magazines

1. "Study The Dimensional Problem of the Tribal Students in India with Special Reference to Kerala State", Nidheesh K.B. School of Management, Pondicherry University, 2008, Source : www.tribalstudentsprobleminindia.

2. "Problems of Undergraduate Tribal Students in North-Western Maharashtra : A Sociological Study Suggestions", Dr. A.S. Paithane, V.V.M.S. Arts \& Commerce College, Akkalkuwa, Journal : International Research Journal - Nov. 2010, Vol. 1, Issue - 14, P. No. 71,72, Source : www.internationalresearchjournal.

3. Socio-Demography, Personality Profile and Academic Performance of Various Categories of Medical Students", R.C. Jilora\&Jugal Kishore, Department of Preventive \& Social Medicine, Maulana Azad Medical College, New Delhi, 1998 Journal :- Indian J. Psychiat. P. No. 231-239.

4. "Difficulties Facing First Year Medical Students in UMM Alqura University in Saudi ARabia" H. Almsallim, S. Aldahlawi, E. Alqaklani, S. Alqurashi, A. Munshi, Department of Medicine, Medical College, UMM Journal, Vol.14, No.2, (2010), P. No. 1272-1277. 
5. "Depression a Problem for Medical Students", TrunNguhen Posted on : Oct-2009, by Marketing and Communication Flinders University, 2009. Source :- www.problemformedicalstudents .

6. "A Study of Stress in Medical Students at Seth G.S. Medical College", Supe A. N. Department of Surgery, Seth G.S. Medical College, Mumbai1998, Vol-44, Issue-1, P.N. No. 1-6, Journal of Postgraduate Medicine.

7. AdivasioniSamasya, Arunbhai Patel, Adilok, Sept.-Oct. 2012 P.13-15.

8. Gujarat $\mathrm{Na}$ AdivasionaVikasnuBadlatuChitra, BachubhaiBaranda, Adilok, Year-4, Vol-5, Sept.-Oct. 2012, P. 28-31.

\section{Dr. Nitinkumar K. Jadav}

